\title{
Enacting “Accountability in Collaborative Governance": Lessons in emergency management and earthquake recovery from the 2010 -2011 Canterbury Earthquakes
}

\author{
Kelum Jayasinghe* \\ Essex Business School (EBS), \\ University of Essex, Colchester, UK \\ Christine Kenney and Raj Prasanna \\ Joint Centre for Disaster Research (JCDR), \\ Massey University, New Zealand \\ Jerry Velasquez \\ Secretariat Office, \\ Green Climate Funds (GCF), \\ Incheon, Republic of Korea
}

Corresponding author: knjay@essex.ac.uk 


\title{
Enacting “Accountability in Collaborative Governance": Lessons in emergency management and earthquake recovery from the $2010-2011$ Canterbury Earthquakes
}

\begin{abstract}
Purpose: The paper illustrates how accountability of collaborative governance was constituted in the context of disaster managerial work carried out by the Government, local authorities, and Māori community organisations, after the 2010-2011 Canterbury earthquakes in New Zealand.
\end{abstract}

Methodology: A case study detailing the communitarian approach to disaster recovery management by a nationalised Māori earthquake response network is contrasted with the formal emergency management infrastructure's response to the Canterbury earthquakes.

Findings: Critical analysis of the effectiveness and failures of these approaches highlights the institutional and cultural political issues that hinder the institutionalization of collaborative and accountable governance in the fields of disaster risk reduction and emergency management.

Implications: The paper contributes to the accountability research and practice in general and disaster accountability in particular by addressing a more multifaceted model of "accountability combined with collaborative governance" as a way to build on and critique some of the seemingly more narrow views of accountability.

Originality: The study presents rare insights on the interactions between formal and community level accountability and collaborative governance in the context of New Public Governance (NPG).

Keywords: Accountability, Collaborative governance, Canterbury earthquakes, disaster management, Sendai framework 


\section{Introduction}

The paper illustrates how "accountability in collaborative governance" was constituted and conducted by nationalized Civil Defence and Emergency Management (CDEM) and regional governmental agencies, such as the Canterbury Earthquake Recovery Authority (CERA) and local Maori earthquakes recovery network, responding to the impacts of the 2010-2011 Canterbury earthquakes in New Zealand (NZ). NZ' 2010 and 2011 earthquake sequence, which is one of the nation's most devastating natural hazard disasters on record (NZ History, 2017), triggered extensive damage across the Canterbury region. Canterbury was heavily affected, especially by the February 22, 2011 earthquake, which killed 185 people and injured 9000 while creating damage to 170,000 buildings and infrastructure already weakened by the Canterbury earthquake of September 2010 and related aftershocks (Canterbury Earthquake Royal Commission, 2012). Economically, it has been estimated that around NZD 20 billion (in 2011 prices) had to be spent on repairing or replacing damaged assets, which was equal to some ten percent of NZ's annual domestic output. In addition, the cost of repairing or replacing residential property damage was estimated as NZD 13 billion, while the reinstatement of commercial damage was estimated to be NZD 4 billion. Moreover, the infrastructure damage repair and replacement was expected to cost NZD 3 billion (Parker and Steenkamp, 2012).

The paper draws on the literature about accountability in the context of "collaborative governance" to contrast two sets of responses to above 2010-2011 earthquakes in Canterbury, NZ. One set of responses are characterised as top down responses at the government level. The other set of responses are related to more local, culturally appropriate Maori Earthquake recovery network. The paper attempts to analyse and characterise the ways these two sets of responses were taken place in the collaborative disaster governance arenas in NZ. The term "accountability in collaborative governance" represents a more multifaceted and holistic model than other narrowly defined conceptions of accountability such as financial, political or social (Taylor et al., 2014). This increased level of plurality occurs because "accountability in collaborative governance" integrates multiple forms of accountabilities - vertical, horizontal, downward and diagonal - surrounded either by collaborative working or cross-organisational working relationships. Critics state (Jayasinghe and Wickramasinghe, 2006, 2011; Sørensen, 2012; Baker, 2014) that the failure of good governance is caused by a lack of mixed accountability standards, such as communication, information and coordination arrangements between collaborative organisations and their work environment. 
A previous study by O'Dwyer and Unerman (2008) revealed how the managers in an Irish NGO historically relied on internal forms of accountability that has been augmented with a range of ad hoc external accountability mechanisms towards a narrow range of (potentially) powerful stakeholders. Realizing the counter-productivity of this approach to achieve their NGO's mission, the NGO leadership later expressed an interest toward a broader and more holistic accountability conceptions. O'Dwyer and Unerman (2008) argued that these findings could create a platform for a holistic accountability practice in NGOs more generally. However, there has been a relative dearth of further studies and discussions on this topic, particularly in the context of private-public settings such as disaster recovery. Having said that this study views Sørensen (2012)'s proposal for a “collective accountability” in New Public Governance (NPG) initiatives as a way forward to the findings of O'Dwyer and Unerman (2008). Sørensen (2012) argued that those who participate in a collaborative working should be collectively accountable for their actions and must produce collective accounts of the issues and problems that have initiated the collaboration (Sørensen, 2012, p. 13). Applying this "collective form of accountability in collaborative governance" framework (Sørensen, 2012), this study contributes to the debate in litearture for a need of holistic accountability in NGOs and publicprivate partnerships, such as disaster recovery. Empirically, the paper demonstrates the problametic nature and the potentail need for enactment of some forms of collaborative accountablity practices and devices in the study context of NZ.

Moreover, this study will add to the disaster accounting and accountability literature. For instance, Lai et al. (2014) investigated the social aspects of the accounting system used by authorities in charge of a recovery process from a devastating flood disaster. They positively claimed that accounting procedures activated after this disaster not only gave visibility to flood damages and recovery actions, but also favored a sense of inter-dependency between all of the players involved. Focusing on the flood events occurred in the State of Victoria, Australia during 2010-11, Sciulli (2017) revealed the role accounting played in addressing the impact of a natural disaster on an individual level. Thus, the local government managers used the accounting information to eradicate evolving some confusion among local councils and rural communities with regard to their eligibility and timing to assess the funding support provided by State and Federal Government. Sargiacomo (2015) demonstrated how the local health authorities applied a set of calculative practices and accounting classification systems to provide the provision of disaster relief funding contingent. In particular, the accounting classification systems were used to identify additional and traceable earthquake-related 
expenditures worked in tandem with disaster related scientific classifications to define the seismic events as a site for exceptional governance, during the emergency responses in 2009 earthquake in Abruzzo, Italy. In their pivotal study, Perkiss and Moerman (2017) applied sociology of worth (SOW) framework to construct a narrative of Hurricane Katrina and explored the multiple rationalities and experiences in relation to 'common good' within disaster related 'social reality". Their study illustrated the contentions, compromises and conflicts, as well as the neglected or hidden accounts required to achieve the common good of disaster related situations. Contrary to them, Baker (2014) examined the breakdowns in accountability during and after the storm which were manifested by a lack of communication between government officials and a failure on the part of officials to act responsibly on behalf of victims, many of whom were poor, black and elderly. In line with this view, Everett and Friesen (2010) examined three leading humanitarian agencies including the Red Cross and revealed how the actors involved in humanitarian assistance programs jeopardize their goals by adhering to a number of contradictory scripts related to neutrality, commerce, and performance. They argue for the inseparability of technical and moral accountability in executing humanitarian relief. Subsequently, Sargiacomo at al. (2014) reported when, how, and with what effects accounting and other associated practices through the three lenses of private-interest maximization, inequality, and suffering were mobilized in the follow-up to an earthquake in central Italy. His findings illustrated how accounting actors simultaneously serve multiple ethical masters, and how one of these can come to dominate accounting's 'moral economy'. Extending the knowledge on these disaster accounting and accountability, the current study will analyze the two contrasting perspectives adopted by the state and the community groups (Maori) during Canterbury natural disasters in NZ. Thus, the later was adopted according to Maori values and practices, as well as their historically established local (Maori) knowledge. The paper will explain how these two approaches could be linked within a common arena of "accountability in collaborative disaster governance".

Intending a contribution to policy, the study reflects the ways in which the concept of "accountability in collaborative governance" may apply collectively to recovery responses and governance policies within disaster recovery contexts involving multiple agencies and actors at different levels. The study adopts a comparative case study approach built around various primary and secondary sources, including three qualitative research projects previously conducted with key stakeholders to analyse the institutional views and participants' 
experiences of the governance impacts of the Canterbury earthquake disasters of 2010 and 2011.

The remainder of this paper is organised as follows. In Section two, the paper discusses the existing literature on disaster accounting and accountability, and presents the analytical model of "accountability in collaborative forms of governance". The research methods are outlined in section three. Section four presents the case study analysis based on the "accountability in collaborative governance" model. This section includes the findings from two cases, the disaster recovery responses from government level and the responses by Maori Earth quake recovery network. The final section contains the discussion and concluding remarks of the study.

\section{Disaster accounting and accountability literature and the "accountability in collaborative governance" model}

Factors associated with enacting accountability in disaster management such as sets of laws, rules, practices and cultural morals are a collective source of concern amongst accounting researchers. This is because of enduring corruption and wastage of public resources, slow disaster recovery responses and continued failure to reach intended target groups where the accountability aspects of disaster management in planning, executing and reporting are questioned (Everett and Friesen, 2010; Baker, 2014; Sargiacomo, 2014; Sargiacomo et al., 2014; Lai, 2014; Taylor et al., 2014; Walker, 2014). The crucial topic of disaster accountability issues is to distinguish between "calculative accountability" and "narrative accountability (Everett and Friesen, 2010; McKernan and McPhail, 2012; Kamuf, 2007; Sargiacomo at al., 2014; Perkiss and Moerman, 2017). The term "calculative accountability" relates to the objective facts, hard evidence, and the numbers, e.g. no of displaced people, cost of damaged properties and accounting records of resource allocations that can depict themselves (Kamuf, 2007). This term also encompasses laws and regulations which create administrative structures that ensure corporate and government accountability to stakeholders including the community and society (Baker, 2014; Sciulli, 2017; Sargiacomo, 2015). In contrast "narrative accountability" in disaster situations relates to emotions and qualitative judgments of the stakeholders, e.g. judgments of the disaster victims regarding the effectiveness of disaster relief efforts (Everett and Friesen, 2010; McKernan and McPhail, 2012; Kamuf, 2007; Baker, 2014; Perkiss and Moerman, 2017). 
However, as previously stated, the application of the term accountability into collaborative working or cross-organisational working relationships creates a more complex phenomenan because of the requirement of multiple forms of accountabilities, namely vertical, horizontal, downward and diagonal from the perspective of government and non-governmental agencies (O'Dwyer and Unerman, 2008; Everett and Friesen, 2010; Hodges, 2012; Taylor et al, 2014; Bakers, 2014; Sargiacomo et al, 2014; Sargiacomo, 2015; Perkiss and Moerman, 2017). As some critics have claimed (Lipton et al., 2005; Everett and Friesen, 2010; Bakers, 2014) the failure of accountability in collaborative working relationships is mainly caused by a lack of proper communication mechanisms between the agencies, e.g. the government organisations, NGOs, external funders and local institutions.

Despite the preceding negative exemplars, O'Dwyer and Unerman's (2008) work highlights that at least at the conceptual level, this horizontal form of accountability between relatively autonomous agencies operating in the same context has the ability to function effectively through relational networks. This horizontal accountability is also conceptually connected with two other forms of accountabilities, namely social accountability and diagonal accountability (Goetz and Jenkins, 2001; Sørensen, 2012). In particular, the social accountability is known as a form of 'society driven horizontal accountability' and expected to demonstrate direct responsibility from government, non-governmental agencies and business organisations to the community and society (Sørensen, 2012; Kohli, 2012). The World Bank's recent introduction of several reporting strategies to the member countries, such as participatory budgeting, social audit, public expenditure tracking, social mobilisation and citizen monitoring, illustrate the importance of this society driven horizontal accountability (World Bank, 2014). That said, by requiring the above reporting strategies, the World Bank also expects to promote a diagonal accountability concept in its member countries by ensuring the direct engagement and watchdog role of its citizens within government and non-governmental organisations.

On a different perspective, new public governance (NPG) discourse has been proclaimed as an alternative governance paradigm to public-sector management, with some suggesting that it replaces classical public administration (CPA) and new public management (NPM) (Pollitt et al., 2004; Bouckaert et al., 2010). NPG intends to transform the fragmented governance capacity within public-sector entities by bringing in greater coordination and collaboration to public-sector activities (Sørensen, 2012). Sørensen (2012) argued that NPG articulates a 
"collective accountability" perspective and that those who participate in a collaborative working embrace are collectively accountable for their actions. For instance, "they must produce collective accounts of the issues and problems that have initiated the collaboration, the applied strategies for dealing with these problems and issues, the activities launched to implement these strategies, and the outcomes that have been produced" (Sørensen, 2012, p. 13). Applying collaborative accountability to a collaborative governance approach to manage disaster contexts is valuable.

This approach pinpoints the importance of establishing an accountability holder (e.g. administrative leaders, disaster victims, resilience community) with the ability to hold other accountability holders (politicians, government organisations, NGOs and private sector entities) with governance responsibilities for collaborative disaster resilience and recovery efforts, collectively to account. The analytical model shown in Figure 1, developed through drawing on Sørensen's (2012) ideas of NPG accountability, is proposed as a mechanism for elucidating understandings about the "accountability of collaborative governance" in the disaster management field.

\section{[Insert the Figure 1 here]}

The collaborative governance arenas of the model can mirror the roles and activities performed by the public, private and non-governmental actors both as accountability holders and as accountability holdees, during the disaster recovery process and practices. The forms of accountability such as calculative and narrative (Everett and Friesen, 2010; McKernan and McPhail, 2012; Kamuf, 2007; Sargiacomo et al., 2014; Sargiacomo, 2015; Perkiss and Moerman, 2017) as well as vertical, horizontal, social and diagonal (Goetz and Jenkins, 2001; Sørensen, 2012) all shape the form of holistic or collective accountability practices within NPG, and more generally the accountability is operating more centrally in the collaborative governance model. On the other hand, by employing a "collective" (Sørensen, 2012) or holistic (O’Dwyer and Unerman, 2008) accountability approach, the collaborative governance model builds and extends all forms of accountabilities in NPG. This phenomenon is being discussed further in the remaining sections of the paper. Through the evidence of two case studies, the paper will highlight how this collective accountability in collaborative governance model enacted in the state responses and the Maori responses during Christchurch disasters. 


\section{Methodology}

The findings of the study were based on the comparative analysis of two cases; state response and Maori community response to Canterbury disasters. Research data was collected from various primary and secondary sources including three qualitative research projects previously conducted with key stakeholders involved in disaster management and recovery efforts in Canterbury. The first project by the first and third author and a pilot study exploring the experiences of members of various disaster management stakeholder agencies tasked with managing the formal response. The analysis of this initial pilot study indicated that there were some recognisable accountability gaps in collaborative working between the disaster management agencies in NZ. In addition, the second author conducted two community-based participatory research projects in partnership with the local Māori community in order to explore Māori tribal responses to the Christchurch earthquakes as well as document and develop understandings about the factors that build Māori resilience.

The two community-based qualitative research projects have been conducted using a Kaupapa Māori research approach, which ensures that research is designed by and for Māori, addresses Māori concerns, is implemented by predominantly Māori researchers and conducted in accordance with Māori cultural values and research practices (Smith, 2012). Te Rūnanga o Ngāi Tahu ${ }^{1}$ and Ngā Hau e Whā ${ }^{2}$ Urban Māori Authority facilitated the recruitment of research participants. participants $(\mathrm{N}=100+)$. Ninety semi-structured individual and group interviews were conducted with participants, during which dialogical (conversational) interviewing techniques (Frank 2005) were used to elicit 120 disaster narratives. Alternatively, the initial pilot study was based on the open-ended interviews with local authority officials in Christchurch and officials in Department of Prime minister and Cabinet (DPMC) New Zealand. Civil Defence and Emergency Management

The findings and reflections from the secondary data were used to verify the overall thrust of findings. The main arguments of the paper were significantly developed from secondary

\footnotetext{
${ }^{1}$ Ngāi Tahu is the local Māori tribe for Christchurch and most of the South Island. Their regional tribal authority is called as Te Runanga o Ngai Tahu (TRoNT) (Lambert, 2014).

${ }^{2} \mathrm{Ngā}$ Hau e Whā means the Four Winds. This implicates a symbolic meeting place for the peoples from everywhere (Foster, 2015).
} 
analysis of reports published by government and non-governmental organisations in NZ and pre-existing published research (see the following references: AERU, 2011; Canterbury Earthquake Recovery Authority, 2014; New Zealand Statutes, 2002; Controller and Auditor General., 2017; ECan Environment Canterbury, 2013; FEMA, 2011; New Zealand Police, n.d.; NZ History, 2017; Statistics New Zealand, 2014a and 2014b.; Department of Prime minister and Cabinet (DPMC) New Zealand, 2017; Treasury New Zealand, 2016; UNISDR, 2005 and 2015). These multiple viewpoints generated from secondary and primary data sources have allowed us for greater and improved triangulation of the findings.

In particular, data from interview narratives were adopted to enrich the analysis, as well as to explain the particular qualitative discourse in relation to the "accountability affairs in collaborative governance". The data were analysed using the narrative analysis method (Bruner, 1986; Denzin, 1989; Rosenweld and Ochburg, 1992). The conceptual themes were identified from the "accountability in collaborative disaster governance" model (Figure 1), e.g. the important information for accountability holders such as institutionalized transparency and communication, performance measurements, public knowledge of disaster recovery programs and publicly accessible evaluations of performance and user satisfaction; mixed accountability standards. This method helped the authors pinpoint, examine, and records patterns (or "themes") within interviews and secondary data. To reduce the risk of de-contextualization of interview talk, transcript texts were analysed in a paragraph format using a narrative unit approach. These themes identified through data and themes drew on the analytical model helped us to describe the collective accountability in collaborative governance phenomenon and address the characteristics of collaborative accountability, authority, agency and actions of two cases.

\section{Case analysis}

This analysis section is organised around two main areas of "accountability in collaborative governance". First, the performances and goal achievements of government institutions, such as CDEM, regional and local councils, Regional Emergency Management Offices, Canterbury Earthquake Recovery Agency (CERA) are outlined. Secondly, Māori responses to the earthquakes as well as their perceptions, levels of satisfaction regarding services offered by government institutions, and attitudes toward the mutual benefits derived from collaboration with government, are discussed. Our evidence presented in this section demonstrates how these 
two main parties have engaged with duplicating, as well as gap filling roles and tasks in the recovery process.

\subsection{Case 1: the "accountability in collaborative governance" in Canterbury: the performances and goal achievements by CERA, CDEM and other government entities}

The government responses to the Christchurch earthquakes in 2010 and 2011 included the establishment of disaster recovery processes led by central government agencies and a Minister other than the Minister of Civil Defence, were indicative of a more flexible approach to the governance, coordination and direction of emergency response and recovery than that envisaged in the CDEM Act and National CDEM Plan operating at the time of both incidents (McLean et al., 2012; Mamula-Seadon and McLean, 2015).

During the September 2010 earthquake, it has been reported that just a few hours after the incident the Christchurch City Council, the Waimakariri District and the Selwyn District; three territorial authorities declared local emergencies and activated their emergency operation centres (EOCs). The regional CDEM Group Emergency Coordination Centre was also activated but did not declare a regional emergency at the group level. At the national level, the national crisis management centre (NCMC) was activated. Two days after the 2010 earthquake an ad-hoc Cabinet Committee on Canterbury Earthquake Recovery was established supported by the new cabinet position of the Minister of Canterbury Earthquake Recovery (MamulaSeadon and McLean, 2015). Likewise, during the February 2011 earthquake, Minister of Civil Defence and Emergency Management declared a state of national emergency for the city of Christchurch. This decision was taken to ensure the superior coordination between central and local authorities, and at the same time a decision was made to relocate Christchurch City and the Canterbury Group Civil Defence organisations to a single Emergency Operations Centre, which was named the Christchurch Response Centre (CRC) (Mamula-Seadon and McLean, 2015). Similar to the 2010 earthquake response, the CRC structure expected to coordinate Recovery, but without a formal Recovery Manager function (Mamula-Seadon and McLean, 2015). In this complex context, the central government and the Ad Hoc Cabinet Committee on Canterbury Earthquake Recovery started to consider a new national disaster recovery governance arrangement. Subsequently, the Canterbury Earthquake Recovery Authority (CERA) was set up as a government department soon after the February 2011 earthquake to lead and co-ordinate the recovery from the earthquakes. After the 22 February 2011 
government recognised that the scale of the recovery needed was beyond the capability of the existing arrangements since the 4 September 2010 earthquake. Drawing international disaster recovery experience, the government decided to establish a single authority with specific powers to focus on the recovery from the Canterbury earthquakes (Controller and Auditor General, 2017). As a result in March 2011, CERA was set up as a government department under the State Sector Act 1988.

As a government department CERA allowed a high degree of central control, with a leadership structure that is expected to act decisively and quickly, and is closely aligned with the Government's priorities within disaster governance arena. CERA expected to serve the earthquake impacted communities of "greater Christchurch", which was defined as the districts of Christchurch City Council, Selwyn District Council, Waimakariri District Council, and the adjoining coastal marine area. CERA's role included: providing leadership and co-ordination for the recovery effort; enabling an effective and timely recovery, monitoring the progress of the recovery; and administering the Act. From the perspective of collaborative governance - as the main accountability holder (controller of other accountability holders), CERA supposed to facilitate transparency and communication between collaborative organisations in order to create wider knowledge and trust among the public on recovery activities and build satisfaction among the disaster victims and broader Christchurch community. However, several significant collaborative accountability issues emerged in the governance of disaster recovery process. The remaining paragraphs will analyse how CERA and CDEM have managed the recovery plans and processes during the Christchurch disaster 2011.

Firstly, the early recovery phase of the 2011 earthquake highlighted that CERA's top-heavy recovery structure did not manage to engage in planning activities at the community level (Mamula-Seadon and McLean, 2015). Likewise, the Auditor General's report presented to the NZ parliament (2017) showed that CERA's role as the coordination agency had also been derailed at the end of Christchurch rebuilding process because the organistaion was not able to engage effectively with all stakeholders and there was break down in the collaborative accountabilty. As stated in the overview of the Auditor General's report:

"it became more challenging for CERA to maintain momentum as the recovery moved into the deconstruction phase. Its role became less clear as it took on responsibility for delivering more projects and programmes. CERA needed to adapt to maintain its 
earlier momentum. Similarly, CERA's leadership of the Central City Recovery Programme began effectively with the publication of the Christchurch Central Recovery Plan, but the actual delivery of the plan was less successful. Engagement with stakeholders suffered from a lack of clarity about the role of the Christchurch Central Development Unit, and there were delays in nearly all of the CERA-led Anchor Projects" (Controller and Auditor General, 2017, p.6).

Secondly, the review of the Civil Defence and Emergency Management response to the 22 February 2011 Christchurch earthquake (McLean et al., 2012) highlighted that following the earthquakes in 2010 and 2011, the Christchurch recovery management lacked proper vertical accountability standards required for collaborative governance of the disaster, i.e. communication and transparency with the community groups and volunteers (Mamula-Seadon \& McLean, 2015). This lack of effective communication created unwarranted delays and tensions in their responses to disaster victims (Solomon, 2012).

This point has been further highlighted by the Auditor General's report (2017) presented to the parliament. It stated:

"CERA did not have an effective approach to managing its Anchor Projects as a coherent programme of work. In my 2012 report, Roles, responsibilities, and funding of public entities after the Canterbury earthquakes, I emphasised the importance of effective collaboration. Throughout the recovery CERA needed to manage tensions with residents, and central and local government. Although agencies were able to work effectively at an operational level, these tensions caused delays at a governance level, particularly with Christchurch City Council. In my view, both CERA and the Christchurch City Council were not as open or transparent with one another as is required for an effective recovery. This caused delays in some programmes. I acknowledge the challenges for an agency like CERA in communicating with a community that is recovering from a disaster, but CERA could have been more effective and efficient in its communication and engagement with the community" (Controller and Auditor General ,2017, p.6).

The community surveys conducted also reflected that the social accountability standards such as public's trust and confidence in information from the government agencies in particular 
CERA has declined over time, and many in the community were not satisfied (Controller and Auditor General, 2017). According to the Auditor General's report (2017) to parliament, a key reason for the decline in trust is that the community didn't feel that they had enough opportunities to influence decision-making about the recovery. It stated:

"CERA increased its expenditure on communications, but it did not adapt or change its approach well enough”.

"Some stakeholders, particularly community groups, felt that the community forum was too focused on Ministers and not enough on the community. They also felt that, because of the confidential nature of the information provided to the forum, members of the forum were limited in their ability to consult with their communities on policy options". "We were told that the early meetings were not well organised and the community was not effectively engaged in managing the meetings or designing a communication strategy for affected communities" (Controller and Auditor General, 2017, p.6, p.43, p.50).

Accepting this limitation in their work, in their learning and legacy reports CERA noted (Controller and Auditor General, 2017):

"Some communities did not trust CERA and that "some consider that the public has not had input into some of the big decisions made".

"It had

- been good at: communication but not engagement - communities felt like they were being talked at, rather than listened to;

- tended to wait until solutions were found before sharing information, which meant that communities did not see the "behind-the-scenes work" of CERA and its partners in planning the recovery; and

- communicated unrealistic time frames, which meant that communities" (p.42).

Thirdly, the recovery management experienced unnecessary duplication of services, and in some cases, experienced non-delivery of essential resources or slow progress in the rebuilding process due to weaknesses in collective accountability standards, such as sub-optimal local and 
multi-agency coordination and collaboration. As reported by Wright (2012) in NZ's online newspaper; Stuff:

"Weaknesses and tensions" between the Christchurch City Council and Civil Defence after the February 22 earthquake "put people and property at risk", an independent review into the emergency response has found. The report into the Civil Defence Emergency Management response to the disaster, released yesterday, found the response "can justifiably be regarded as having been well-managed and effective. However, it said "the duplication of control . . . between Christchurch city [council] and the regional [Civil Defence Group] was not only inefficient but put people and property at risk. It recommended local government play no part in controlling future emergency responses, but that has not been adopted by the Cabinet".

Highlighting the weaknesses of horizontal accountability standards and collaborative governance between CERA and Christchurch City Council in the rebuilding process, the Auditor General's report (2017) also stated:

"After 2013 report, CERA strengthened its leadership role with Stronger Christchurch Infrastructure Rebuilding Team (SCIRT) and its monitoring of the Crown's expenditure on the horizontal infrastructure rebuild through its Horizontal Infrastructure team. This helped reduce the cost to the Crown of the horizontal infrastructure rebuild. However, its earlier lack of leadership meant that levels of service and funding arrangements were not effectively agreed between the Crown and Christchurch City Council. This caused tensions between the Council and the Crown and led to significant delays in some projects later in the programme” (p. 35-36).

Fourthly, it was evident that critical collaborative governance issues such as relational disconnections and tensions existed between local and regional governance entities, emergency management stakeholders, and more broadly the national emergency management infrastructure. These negative governance outcomes, such as tensions, which were due to situational and local political factors, created more problamatic accountabily standards, such as a lack of clarity around the delegation of, and authority or power to implement response actions in a cohesive manner as well as a lack of trust between key response stakeholders 
(McLean et al., 2012; Mamula-Seadon and McLean, 2015). The Auditor General Report (2017) to Parliament for example, highlighted:

“Communication between CERA and Christchurch City Council was not as open and transparent as is required for an effective recovery, which damaged the trust between the leadership of both organisations. This caused delays, such as to the repair of pipes and roads, as we reported in 2016” (p. 38)

The report further added:

"At times, CERA failed to prioritise its relationship and leadership role with Wellington-based government agencies. The lack of clarity in its role made it more challenging for CERA to influence and coordinate the work of the wider public sector" (p.36).

MCDEM in their National Capability Assessments conducted for the period 2009-2012 (MCDEM, n.d.a), identified the strategic importance of collaborative governance to disaster recovery and highlighted that the region-wide and all-agencies coordinating role of CEGs was not as well developed throughout the country even after the introduction of the reforming approach intended by the CDEM Act. However, there were instances of a mature and effective approach to comprehensive emergency management being implemented in some regions. Despite the requirement for multi-agency representation on regional CEGs, and for CDEM Groups to take a comprehensive emergency management (CDEM Act section 3(f) and allhazards approach (by way of the definition of "emergency management" in CDEM Act section 4) for collaboartive governance, there was a tendency for the CEGs' foci to be on readiness for natural hazards and the local government component of emergency management. These foci were attributed to the governance bodies for each CDEM Group being made up exclusively of local authority elected members, as well as influence from the more natural hazards and response-focused Civil Defence Act 1983. The situation that developed during the September 2010 and subsequent Canterbury quake responses, where collaborative accountability standards such as local to regional (and, in some instances, multi-agency) coordination was less than optimal can be traced back in part, to the tenuous political and inter-organisational relationships within the region in the few years prior to the 2010-2011 earthquakes (MamulaSeadon and McLean, 2015). 
Similarly, the collaborative accountability standards such as multi-agency coordination during the earthquake responses could have been more effective if several of the agencies involved had met their regional CDEM Coordinating Executive Group (CEG) "active representative" responsibilities as specified in the CDEM Act section 63. Overall, there was a lack of involvement (or engagement) of some important accountability holders, e.g. senior elected officials in bodies such as CDEM Group Joint Committees, resulting in inadequate organisational preparedness, and relatively disjointed risk reduction, response and recovery efforts (McLean et al., 2012; Mamula-Seadon and McLean, 2015). Acknowledging this critical issue, the Auditor General's report (2017) to parliament further recommended:

"Governance arrangements need to be reviewed for each phase of the recovery, and when activities change. This will ensure that governance arrangements are fit for purpose; delivering the recovery agency's outputs and outcomes in the most effective and efficient way. However, particular attention needs be given to the clarity of role definition between the responsibilities of governance and management at both an organisational and project level” (p.9).

Overall, these findings indicate that both national and regionally coordinated formal disaster management at the time of the post-earthquake disasters in Canterbury was largely hampered due to the failure of main accountability holders (e.g. CERA) to keep other accountability holders, such as government organisations, professionals and businesses in control. This has resulted in creating relatively weak "mixed accountability standards" within the Canterbury's "collaborative disaster governance" framework. Specific accountability issues included ineffective implementation of standard performance measurements, a lack of institutional transparency, and inadequate multi-agency communication. Thus, there were considerable collaborative accountability concerns among people and community groups in relation to the coordination arrangements, political roles as well as information support and communication (McLean et al., 2012; Mamula-Seadon and McLean, 2015, AERU - Lincoln University, 2011). These issues extended into relational linkages with broader stakeholder groups and discrete communities residing within Canterbury including the local Māori community. In the next section, Māori collaborative responses to the sequence of major earthquakes in the Canterbury Region and related accountability are explored. Māori concerns regarding the emergency management infrastructure are also outlined. 
Case 2: the accountability in collaborative governance: Maori perspective during the emergency management process in Canterbury

According to the New Zealand 2006 census figures, when the February $22^{\text {nd }} 2011$ earthquake occurred in Christchurch, the urban Māori community comprised 25,725 individuals, and constituted $4.1 \%$ of the urban population, with the local tribe Ngāi Tahu comprising a minority 42\% (10,965) of the Māori demographic (Lambert, 2014). Moreover, Christchurch City Council household estimates (2010), indicated that Māori residents were geospatially concentrated in the low decile Easter Suburbs of Christchurch, which were the areas of the city that were most severely impacted by the February earthquake. In comparison with the wider community of Christchurch, it can thus be argued that the majority of Māori were disadvantaged due to disproportionately reduced access to financial resources, basic necessities, utilities, transport and support services (Paton et al., 2014). As a counter strategy, the Maori community has utilized their own Maori earthquake recovery network for the disaster recovery.

\section{Maori earthquake Recovery Network}

When the earthquakes occurred in Christchurch New Zealand during 2010 and 2011, the local Māori iwi (tribe), Te Rūnanga o Ngāi Tahu, had a cultural obligation to ensure the wellbeing of all Christchurch residents as well as the wider region (Solomon, 2012). After the February 22, earthquake in 2011, the Iwi (tribe) initiated a meeting with Māori representatives from the Christchurch Urban Māori Authority, the Ministry of Māori Development, Māori parliamentarians, the New Zealand Police, NGOs and other tribes (Paton et al., 2014; Kenney and Phibbs, 2015) and established a nationalised Māori response network. The Ngāi Tahu (local Māori tribe) as the regional iwi. Te Rūnanga o (tribal authority) have given the responsibility as an accountability holder for collaborative governance tasks of the Maori network, including the coordination of community support as well as communicated and negotiated decision-making with NGOs, other iwi (tribes) Māori stakeholders, as well as central government and local authorities (Kenney \& Solomon, 2014). This process facilitated a collaboratively governed and well-integrated Māori response to the earthquakes, in that the Network's emergency management practice was characterised by collaborative accountability standards, such as responsibility, authority, agency, and actions, in accordance with Māori 
values $^{3}$ (Kenney \& Phibbs, 2015). Māori share a collective 'ensemble' identity that is genealogically linked across social communities, tribes and land (Kenney \& Phibbs, 2015). Framed with the collaborative gaze of a Māori world view, the earthquakes may be considered catalysts that enabled expression of traditional communitarian governance features including behaviours and the revitalisation of traditional disaster management values and risk mitigation practices. Māori disaster management governance in the Christchurch context was shaped by the value kaitiakitanga (social and environmental stewardship), which imposed an obligation on all Māori involved in the response to care for flora, fauna, regional residents, evacuees and the broader environment. The notion of relational or collective accountability to one's family, and tribe for the wellbeing of community and one's place of belonging is also intrinsic to this value.

Collective accountability strengthens kotahitanga (collective unity) which underpins Māori collaborative responses to adverse conditions. Unity is equally a hallmark characteristic of Māori whānau (families), which serve as the foundation of Māori identity and thus, the source of bonding social capital (Putnam, 2000) within Māori communities. Whakapapa (genealogy) also encompasses collective familial responsibilities, including the delegation of emergency management roles and in combination with the value whakawhanaungatanga (relational linkages) collective authority, agency and reciprocal support arrangements. Manaakitanga (collective actions) constitutes the realisation of Māori collective authority and agency through collaborative enactment of disaster management practices. The value-driven Māori communitarian approach to disaster governance and management instituted in Christchurch was effective and accords with best disaster management practices outlined in the Hyogo Framework for Action (UNISDR, 2005) and Sendai Framework for Disaster Risk Reduction (UNISDR, 2015). However, this collectivist response was oppositional to the more commonly applied 'command and control' approach to disaster management, that was adopted by CDEM and CERA responders following the earthquakes.

\footnotetext{
${ }^{3}$ The common values and beliefs of Māori community are endured around land, water, and air as the basic constituents of life that are to be valued and continued. It embraces around three fundamental concepts known as Whakapapa: genealogical descent, lineage; Mauri: the life force, the crucial principle of being, an energy that pervades through all living things; and Ritenga: custom, rules, regulations, protocols, comprises rāhui and tapu (ritual prohibition/restriction of the access to an area - either on water or land or resources) (Taiuru, 2015).
} 


\section{Emergency Management Governance, Infrastructure and Engagement with Māori}

The lack of relational engagement by Canterbury Civil Defence resulted in the Māori disaster response network being inadequately integrated with the formal emergency governance infrastructure during the initial response to the earthquakes (Phibbs et al., 2015). As the Te Rūnanga o Ngāi Tahu tribal Chairman stated:

"It was a bit slow in us getting involved with the authorities, in fact, it took us eight days to break in... and establishing contact was... difficult.” (SMS)

Māori engagement with the emergency management infrastructure was eventually negotiated through drawing on a pre-existing collaborative relationship with a corporate stakeholder involved in post-earthquake lifelines logistics (Phibbs, Kenney \& Solomon, 2015). The representation of Maori in the formal/national emergency management structure, as an accountability holder, also created diagonal accountability relations between the CDEM, CERA and Maori. Maori acted as the watchdog organisation within the formal disaster recovery system. However, the delay in integrating Māori resources contributed to unnecessary duplication as well as gaps in the distribution of material support to Christchurch residents (Kenney, 2016). Māori rationalised the weak horizontal and social accountability standards, such as poor level of communication and engagement between Civil Defence and the Māori community-led response network, as the product of emergency managers' perceptions of Māori as socially invisible within the region. A Canterbury-based Ngāi Tahu (local Māori tribe) leader commented as follows:

“We're not visible in civil defence. That's why it's like this [difficult], because we're not visible in there as Ngāi Tahu” (RT).

The research participant's talk suggests that in addition to the absence of recognition for cultural identities, cultural attributes including local indigenous knowledge and practices on natural disasters were also not acknowledged. Local knowledge is a key element in developing successful and contextually relevant disaster risk reduction governance strategies (Sendai Framework for Disaster Risk Reduction, 2015). The lack of collaborative governance characteristics such as recognition by the government for Māori knowledge pertaining to the 
Canterbury region was thus a major concern. As another Ngāi Tahu (local Māori tribe) responder remarked:

"We know our communities; we know our marae..., our resources, our whenua" (AC)

The importance of integrating Māori community knowledge, and cultural attributes into disaster governance strategies as a means to address community needs, is also highlighted. In the Christchurch context, the Māori Recovery Network's initial difficulties engaging with the formal emergency infrastructure and integrating response initiatives were eventually resolved (Kenney, 2016). However, members of the broader Māori community also experienced ongoing accountability and disaster governance challenges when attempting to access resources supplied by central government and/or local authorities. Displaced Māori members reported about poor social accountability standards within national disaster recovery networks; e.g. feeling marginalised by Recovery Assistance Centre responders, and systematic cultural insensitivity. As illustrated in the following research participant's talk:

“... when they opened up the... welfare centres so that people could go and stay there.... They were not Màori friendly and... what it meant during the February one [earthquake], was that a lot of Māori ... wouldn't go to the centres... So that is why it was so important that we got the marae open for them" $(K R)$

Another critical social accountability standard was the lack of trust in the effectiveness of welfare centres and response personnel is inferred in the preceding talk. It is equally suggested that the central government's ability to be culturally responsive to whānau (families), following the earthquakes, was inadequate. Within the post-earthquake context, the accountability standards such as lack of trust and perceptions of inadequate responsiveness to the needs of the community were compounded by critical lapses in collaborative accountability standards, e.g. miscommunication and a lack of engagement between Māori and government agents. Although the central government established outreach hubs for key ministries at welfare centres, many Māori, who despite having no power, water or in some instance homes, struggled to access support, particularly financial assistance (Kenney and Phibbs, 2014). As one elderly Māori stated: 
"I didn't have any problem filling out the forms; the problem was the person on the other side of the counter couldn't activate them properly. There was always an issue .... The wrong form... the wrong answers... I'd come out feeling really stressed out about it, .... Yeah really as if it was a type of abuse, you know .... Anyway, it took several goes to sort it out...” $(R N)$

As a collaborative accountability standard, the establishing contextually relevant and culturally responsive welfare centres on Māori was advocated as a means of addressing shortfalls in support, as well as ensuring that Māori residents' needs were fully met. As activation of all Ngāi Tahu marae (Māori community centres) occurred within a week of the February $22^{\text {nd }}$ earthquake, community access to essential resources and support was assured through the Māori Recovery Network. Led by the accountability holder Te Rūnanga o Ngāi Tahu (regional tribal authority), the nationally collaborative Māori Earthquake Recovery Network acted efficiently and provided support in the form of shelter, food water, clothing medical and social services to approximately 20,000 households.

The characteristics of collaborative governance and holistic accountability standards evidenced in Māori approaches to disaster management in Christchurch has strengthened intra and intertribal ties throughout NZ and fostered working relationships between Māori, government and local authorities. The effectiveness of the Māori response to the Canterbury earthquakes has also drawn attention to the need for NZ's Defence and Emergency Management infrastructure to institute a fully integrated response to major natural hazard events in the future. Next section presents the overall findings and conclusion of the two case study analysis.

\section{Discussion and conclusion}

This paper has aimed to advance our understanding of the shaping of "accountability in collaborative governance" in disaster management context. Prior research has empirically examined the disaster accounting and accountability in diverse contexts and questioned the form of reporting pratcices adopted by disaster management agencies (Everett and Friesen, 2010; Baker, 2014; Sargiacomo et al., 2014; Lai, 2014; Taylor et al., 2014; Sargiacomo, 2015; Sciulli, 2017). Few other researchers attempted to distinguish between "calculative" and "narrative" forms of accountabilities (McKernan and McPhail, 2012; Kamuf, 2007; Sargiacomo, 2014) and scrutinized the moral and emotional boundaries of disaster 
accountability (Everett and Friesen, 2010; Baker, 2014; Sagiacomo, 2014; Perkiss and Moerman, 2017). The study was also interested on the work of O'Dwyer and Unerman (2008) and their idea of creating a platform for holistic accountability practices in NGOs. This study has sought to develop and extend this strand of research by examining the collective (Sørensen, 2012) or holistic (O’Dwyer and Unerman, 2008) nature of accountability practices that exist in the "collaborative governance arena" of disaster recovery. During the aftermath of the disasters; the government agencies, community networks and other agencies as accountability holders of "collaborative governance arena" engage with collaborative working and discursively form and exercise multiple forms of accountabilities, e.g. vertical, horizontal, social and diagonal, by shifting and adapting their attention and focus on the urgent disaster recovery aims and activities.

The study compared and contrasted two cases identified from the Christchurch earthquakes in New Zealand, firstly the top down state responses led by CDEM and CERA, and secondly the Maori earthquake Recovery Network responses adhering to their values and practices. The empirical findings of the case one illustrated some critical lapses in relation to the vertical, horizontal and social accountability standards during the Christchurch earthquake recovery, including a lack of transparency, communication and collaboration in work relations between disaster relief organizations. Māori communities lived in Eastern Christchurch were particularly disadvantaged in this regard. These findings manifest the importance of institutionalizing "mixed accountability standards" in collaborative disaster governance arena involving key accountability holders. The ongoing politics among CERA, Christchurch City Council and others regarding the ownership and mechanisms of service delivery, detracted from effective collaborative governance. At the time of Canterbury earthquakes, the lack of genuine efforts by key accountability holders such as CERA and CDEM to establish collaborative working relationships with Māori community, equally disrupted the implementation of mixed accountability standards in collaborative disaster governance arena.

On the other hand, the responses learned from the Māori earthquake Recovery Network and their integration and interaction with state recovery process in later stages of recovery suggest that these community networks as social and diagonal accountability holders can enhance the mixed accountability standards pursuing a "collaborative working" and "collaborative governance" system. In fact, they can articulate the social and diagonal forms of accountability standards particularly into collaborative work relationships and widely to collaborative 
governance arena. As suggested by case evidence, they performed the role of a watchdog organization in the governance arena and represented the voices of wider Maori community. They also shared their historically and culturally established knowledge on indigenous disaster mitigation practices with other key accountability holders in collaborative disaster governance arena.

However, based on the questions raised by Messner (2009) and Roberts (2009), the accountability and transparency always have limits in their practice because of the existence of moral and ethical boundaries, as well as the limits of the accountable self faces when giving an account. Using Butler's (2005) work, they argued that the ideals of a complete transparency or accountability could be considered as an impossible fantasy even though it is widely shared among the policies and practice, in this case the disaster recovery. Therefore, the performance of accountability holders and maintenance of any mixed accountability standards in "collaborative disaster governance arena" - either from the government (formal process), Maori (socio-cultural process) or integrated/joint perspective, would depend largely on the subjections and individual recognitions of the accountable self.

The paper contributes to prior research on disaster accounting and accountability (Everett and Friesen, 2010; Hodges, 2012; Taylor et al., 2014; Bakers, 2014; Sargiacomo et al., 2014; Walker, 2014; Sargiacomo, 2015; Perkiss and Moerman, 2017; Sciulli, 2017) and O'Dwyer and Unerman's (2008) holistic accountability debate in several interrelated ways. First, it showcases how combinations of upward, downward, horizontal and diagonal accountability standards (both in calculative and narrative forms) can be effectively integrated into one "collaborative disaster governance arena" through the mixing of two contending responses to disasters: the formal (state) and socio-cultural (Maori) responses. The "collaborative disaster governance" arena concurrently creates the space for both (i) socio-cultural and diagonal accountability standards based on Maori values and practices, and (ii) more formal bureaucratic and scientific accountability measures regulated by the State. Second, the study findings have also highlighted the need for meta-governing parameters, including institutional design of governance arenas, political, budgetary, legal and discursive framing, as well as facilitation of inter-organizational and community participation in collaborative governance. These practices will facilitate the institutionalization of a form of collective accountability standards in the collaborative governance arenas. 
The paper's findings reflect the importance of having several accountability policies at the national disaster management level. First, the analysis of Māori experiences and responses suggests that establishing national accountability processes for pre-disaster preparedness and short-term recovery is paramount. It seems vital to establish an efficient collaborative managerial culture in disaster mitigation and build trust across the various sectors. Second, the experiences gained from responding to the Canterbury earthquakes highlight the necessity of establishing "contingency plans" for accountability under special conditions. During the aftermath of a major disaster, for example a collaborative co-governance approach to recovery could ensure the proper transparency of governance during the stages of rehabilitation and reconstruction until full recovery has been achieved. The study's analysis of emergency management governance, infrastructure and engagement with Māori network suggests that effective partnership and collaboration around the principles of transparency, governance, and that communication of accountability information between key disaster management agencies and community level stakeholders, need to be embedded at every level of response including government policy.

The paper presents critical reflections based on the study of two cases during the aftermath of Canterbury disasters occurred in 2010 and 2011. However, it has to be acknowledged that New Zealand is recognised as a country which sets an example for other Sendai Framework signatory countries on strengthening their own collaborative governance and accountability activities, as well as measures based on the lessons learnt and experiences of previous events. It should highlight that the New Zealand Civil Defence has strengthened existing conversations, and also initiated new dialogues with various sectors of society with a view to developing a new national resilience strategy since the Christchurch earthquakes (MCDEM, n.d.b). Having experienced several recent events such as Seddon and Kaikoura earthquake sequences and Port Hills fires, it is evident that the government has introduced policy level improvements based on the lessons learnt from the Christchurch Earthquake. One such example is the recent government Bill for the Hurunui/Kaikoura Earthquakes Recovery (2016). Relating to the contents of this Bill, the Department of the Prime Minister and Cabinet (DPMC) produced a regulatory impact statement to help inform the main policy decisions taken by the Government (The Treasury New Zealand, 2016). It establishes the essential requirements of engaging with substantially affected persons and requiring the Minister to take into consideration their comments, delivers a greater degree of transparency and accountability, and provides for participatory rights to check on the Executive. Also recently in late July 2017, 
DPMC released a commissioned report: Whole of Government Report: Lessons from the Canterbury earthquake sequence prepared by the Greater Christchurch Group (2017). This report is based on more than 200 published articles related to the recovery from the Canterbury earthquake sequence. The report has identified nearly 50 lessons across various topic areas and offered government's perspective on the lessons drawn from the recovery efforts. Among the identified lessons, four lessons concern with public participation and community engagement having considered the evidence-based limitations and criticisms.

Finally, from the lessons learned in emergency management and earthquake recovery from the 2010 -2011 Canterbury Earthquakes illustrate that there is still more opportunities for further research about natural disasters, including COVID-19 pandemic disease in 2020, and academics should devote more efforts on this topic, as for the true "impact" that focused research might have on organizations and societies. The COVID-19 is more severely felt than those of some other natural disasters in the past (Sargiacomo, 2014, 2015), mainly because of its deeply risen numbers of deaths and infections as well as significant institutional challenges and socio-economic damages caused in many countries. It's really important and timely, therefore, to examine the COVID-19 disaster recovery responses and policies by different countries, and explore the challenges and failures, and sometimes, unintended consequences of "accountability in collaborative governance" mechanisms among different levels of government organizations, businesses, NGOs and community level organizations within each country.

\section{References}

AERU - Lincoln University (2011). Recovery strategy for greater Christchurch: Summary and analysis of written comments on draft Recovery Strategy. CERA Canterbury Earthquake Recovery Authority, Retrieved from:

http://cera.govt.nz/sites/default/files/common/draft-recovery-strategy-summary-andanalysis-of-written-comments.pdf

Baker, C. R. (2014). Breakdowns of accountability in the face of natural disasters: The case of Hurricane Katrina. Critical Perspectives on Accounting, 25(7), 620-632.

Blaikie, N. (2000). Designing Social research: The logic of anticipation, Polity Press, Malden, MA, Oxford Cambridge. 
Bovens, M. (2005). "Public Accountability." In Ferlie, Ewan. Laurence E. Lynn, Jr. \& Christopher Pollitt (eds). The Oxford Handbook of Public Management. Oxford: Oxford University Press.

Bruner, J. (1986). Actual Minds, Possible Worlds. Cambridge: Harvard University Press.

Butler, J. (2005). Giving an Account of Oneself, New York: Fordham University Press.

Canterbury Earthquake Recovery Authority (2014), Briefing for the incoming Minister October 2014, page 13.

Carville, O., \& Scott, M. (2016, Feb 17). Christchurch earthquake: Eerie images of city's redzone, five years on. NZ Herald. Retrieved from: http://www.nzherald.co.nz/nz/news/article.cfm?c_id=1\&objectid=11591021

Civil Defence and Emergency Management Act, New Zealand Statutes (2002). Retrieved from http://www.legislation.govt.nz/act/public/2002/0033/25.0/DLM149789.html

Controller and Auditor General. (2017). Canterbury Earthquake Recovery Authority: Assessing its effectiveness and efficiency. Office of the Auditor Genera, New Zealand, Retrieved from https://www.oag.govt.nz/2017/cera/docs/cera.pdf

Denzin, N.K. (1989). Interpretive Interactionism. Newbury Park, CA: Sage.

Department of Prime minister and Cabinet (DPMC) New Zealand. (2017). Commissioned report: Whole of Government Report: Lessons from the Canterbury earthquake sequence. Greater Christchurch Group (GCG), the Department of Prime minister and Cabinet (DPMC) New Zealand. Retrieved from:

https://www.dpmc.govt.nz/sites/default/files/2017-07/whole-of-government-reportlessons-from-the-canterbury-earthquake-sequence.pdf

ECan Environment Canterbury. (2013). Media Release 19 February 2013: Important steps taken in Ngāi Tahu, Environment Canterbury Partnership. Retrieved 16 April 2014 from:http://ecan.govt.nz/news-and-notices/news/Pages/ngai-tahu-environmentcanterbury-partnership.aspx 19/2/2013

Everett, J., and Friesen, C. (2010). "Humanitarian accountability and performance in the Théâtre de l'Absurde, Critical Perspectives on Accounting, vol. 21, Issue 6, pp. 468485.

FEMA (2011). National Disaster Recovery Framework Strengthening Disaster Recovery for the Nation, US Department of Homeland Security.

Foster, T. M. (2015). Whānau Whānui: Investigating the Plausibility of an Organisational Model Based on Customary Whānau Values, A Thesis presented for the Degree of 
Master of Philosophy Māori Studies, Massey University, Palmerston North New Zealand.

Goetz, A.M. and Jenkins, R. (2001). "Hybrid Forms of Accountability: Citizen Engagement in Institutions of Public Sector Oversight in India.” Public Management Review 3 (3): 363-383.

International Organization of Supreme Audit Institutions (IOSAI) (2015). The Integrated Financial Accountability Framework (IFAF), Retrieved from: www.issai.org.

Jayasinghe and Wickramasinghe, D. (2006). Can NGOs Deliver Accountability, Predictions, Realities and Difficulties. In H. Bhargava \& D. Kumar (Eds.), NGOs: Roles and Accountability (pp. 296-327). ICFAI Books and Publications.

Jayasinghe, K., \& Wickramasinghe, D. (2011). Power over Empowerment: Encountering Development Accounting in a Sri Lankan Fishing Village, Critical Perspectives on Accounting (CPA), 22(4), 396-414.

Kamuf, P., (2007). “Accountability”, Textual Practice, Vol. 21, No. 2, pp. 251-266.

Kenney, C. and Phibbs, S. (2015). A Māori Love Story: Community-led Disaster Management in response to the Ōtautahi (Christchurch) Earthquakes as a framework for action. International Journal of Disaster Risk Reduction, Vol. 14, No. 1, 46-55. Retrieved from: http://dx.doi.org/10.1016/ijdrr.2014.12.010

Kenney, C. and Solomon, Sir M. W. (2014). Māori Community-led Disaster Risk Management: An effective response to the 2010-2011 Christchurch Earthquakes. UNISDR Scientific and Technical Advisory Group Case Studies, Retrieved from http://www.preventionweb.net/files/workspace/7935_kenneyandsolomon.pdf

Kenney, C. (2016). Engaging the 'Other': Māori, urban recovery and resilience planning in Christchurch, New Zealand in the aftermath of the 2010-2011 Earthquakes In H. James and D. Paton (Eds.) The Consequences of Disasters: Demographic, Planning and Policy Implications. Springfield, Chicago, Illinois: C H Thomas.

Kenney, C., Paton, D., Johnston, D., Reid, J. and Phibbs, S. (2012). Addressing Risk and Resilience: An analysis of Māori communities and cultural technologies in response to the Christchurch earthquakes IDRC Davos 2012 Integrated Risk Management in a Changing World - Pathways to a Resilient Society Compendium, pp. 373-376.

Kenney, C., Phibbs, S., Paton, D., Reid, J. and Johnston, D. (2015). Community-led Disaster Risk Management: A Māori Response to the Ōtautahi (Christchurch) 
King, D., Goff, J. and Skipper, A. (2007). Māori environmental knowledge and natural hazards in Aotearoa-New Zealand. Journal of the Royal Society of New Zealand, 37(2), 59-73., Retrieved from: 10.1080/03014220709510536.

Kohli, D.S. (2012). Manual on Social Accountability: Concepts and Tools, Centre for Budget and Governance Accountability, New Delhi, India, Oxfam - Novib: Netherlands.

Lai, A., Leoni, G. and Stacchezzini, R. (2014). "The socializing effects of accounting in flood recovery", Critical Perspectives on Accounting, Vol. 25, Issue 7, pp. 579-603

Lambert, S. (2014) Indigenous Peoples and urban disaster: Māori responses to the 2010-12 Christchurch earthquakes, Australasian Journal of Disaster and Trauma Studies, Vol. 8, No1, pp. 39-48.

Latour, Bruno., (2005). Reassembling the social: An introduction to actor-network-theory, Oxford University Press, Oxford, New York, NY.

Mamula-Seadon, L., and McLean, I. (2015). Response and early recovery following 4 September 2010 and 22 February 2011 Canterbury earthquakes: Societal resilience and the role of governance. International Journal of Disaster Risk Reduction, 14, 82-95.

McKernan, J.F. and McPhail, K. (2012). Accountability and accounterability", Critical Perspectives on Accounting, Vol. 23 No. 3, pp. 177-182.

McLean, I., Oughton, D., Ellis, S., Wakelin, B., \& Rubin, C. B. (2012). Review of the civil defence emergency management response to the 22 February Christchurch earthquake. Wellington, NZ: New Zealand Ministry of Civil Defence and Emergency Management.

McNeil, M. \& T. Mumvuma. (2006). Demanding Good Governance: A Stocktaking of Social Accountability Initiatives by Civil Society in Anglophone Africa. Washington DC: WBI Working Paper No.37261.

McSaveney, E. (2017). Historic earthquakes - The 2011 Christchurch earthquake. Te Ara - the Encyclopedia of New Zealand.

Retrieved from http://www.TeAra.govt.nz/en/historic-earthquakes/page-13

Messner M. (2009). The limits of accountability. Accounting, Organizations and Society, Vol. 34 No. 8, pp. 918-38.

Ministry of Civil Defence and Emergency Management (MCDEM). (n.d.a). National Capability Assessments. Retrieved from http://www.civildefence.govt.nz/cdemsector/monitoring-and-evaluation/national-capability-assessments/

Ministry of Civil Defence and Emergency Management (MCDEM) (n.d.b). National Disaster Resilience Strategy development, Retrieved from 
http://www.civildefence.govt.nz/cdem-sector/national-disaster-resilience-strategydevelopment/

New Zealand Parliament (d.n.a). https://www.parliament.nz/en/visit-and-learn/howparliament-works/parliamentary-practice-in-new-zealand/chapter-43-emergencypowers/

New Zealand Police. (n.d.). List of deceased, Retrieved from: http://www.police.govt.nz/major-events/previous-major-events/christchurchearthquake/list-deceased

NZ History. (2017). Christchurch earthquake kills 185. Ministry for Culture and Heritage, Retrieved from: https://nzhistory.govt.nz/page/christchurch-earthquake-kills-185

O'Dwyer, B and Unerman, J. (2008). "The paradox of greater NGO accountability: A case study of Amnesty Ireland", Accounting, Organizations and Society, vol. 33, no. 7-8, pp. 801-824.

Parker, M. and Steenkamp, D. (2012). Reserve Bank of New Zealand: Bulletin, Vol. 75, No. 3 , September 2012

Paton, D., Johnston, D., Mamula-Seadon, L. and Kenney, C. M. (2014). Recovery and Development: Perspectives from New Zealand and Australia. In N. Kapucu, \& K. T. Liou, (Eds.) Disaster \& Development: Examining Global Issues and Cases (pp. 255273). New York, NY: Springer.

Perkiss, S. and Moerman, L. (2018). "Hurricane Katrina: Exploring justice and fairness as a sociology of common good(s)", Critical Perspectives on Accounting, In press, corrected proof Available online 6 December 2017, Article 102022.

Phibbs, S., Kenney, C. and Solomon M. (2015). Ngā Mōwaho: An analysis of Māori responses to the Christchurch earthquakes. Kotuitui: New Zealand Journal of Social Sciences Online, 10(2), 72-82, DOI: 10.1080/1177083X.2015.1066401

Potter, S. H., Becker, J. S., Johnston, D. M., and Rossiter, K. P. (2015). "An overview of the impacts of the 2010-2011 Canterbury earthquakes", International Journal of Disaster Risk Reduction, 14, 6-14.

Proctor, E. M. (2010). Toi tu te whenua, toi tu te tangata: A holistic Māoir Approach to flood management in Pawarenga, Masters Thesis, Waikato University, Hamilton, New Zealand.

Putnam, R. (2000). Bowling Alone: The Collapse and Revival of American Community, Thomas and Schuster Paperbacks, New York, NY. 
Roberts, J. (2009). "No one is perfect: the limits of transparency and an ethic for intelligent accountability," Accounting, Organizations and Society, 34(8): 957-70.

Rosenwald, G.C. and Ochberg, R.L. (1992). eds. Storied Lives: The Cultural Politics of SelfUnderstanding. New Haven: Yale University Press.

Sargiacomo, M. (2014). "Accounting for Natural Disasters \& Humanitarian Interventions", Critical Perspectives on Accounting, Vol. 25, Issue 7, pp. 576-578.

Sargiacomo, M. Lanni, L. and Everett, J. (2014). “Accounting for suffering: Calculative practices in the field of disaster relief", Critical Perspectives on Accounting, Vol. 25, Issue 7, pp. 652-669.

Sargiacomo, M. (2015). "Earthquakes, exceptional government and extraordinary accounting", Accounting, Organizations and Society, Vol 42, pp. 67-89.

Sciulli, M. (2018). "Weathering the storm: Accountability implications for flood relief and recovery from a local government perspective", Financial Accountability and Management, Vo. 34, Issue pp. 30-44.

Smith, L. (2012). Decolonising Methodologies: Research and Indigenous Peoples. (2 ${ }^{\text {nd }}$ edn). London, New York: Zed Books

Solomon, M. (2012). Keynote Address. Recover Reconnect Rebuild. MASS (Māori Academy of Social Science) Conference. 28-30 November, Canterbury University, Christchurch.

Sørensen, E. (2012). "Measuring the accountability of collaborative innovation", The Innovation Journal: The Public Sector Innovation Journal, Vol.17, No.1, pp. 1-18.

Statistics New Zealand (2014b). Five largest Iwi by population for Greater Christchurch 2006 and 2013 Censuses. Retrieved July 29 2014, from http://.stats.govt.nz/Census/2013census/profile-andsummary-reports/quickstats-about-greater-chch/cultrualdiversity.aspx

Statistics New Zealand (2014a). Maori Population of Christchurch City and New Zealand 2006 Census, Retried from:

http://www.stats.govt.nz/Census/2006CensusHomePage/QuickStats/AboutAPlace/Sn apShot.aspx id=2000060\&amp;type=ta\&amp;ParentID=10000133

Taiuru, K. (2018). Introduction to Tikanga Māori Considerations with Genomics, Retrieved from http://www.taiuru.maori.nz/wp-content/uploads/Introduction-to-Tikanga-Maoriconsiderations-with-Genomics.pdf

Taylor, D., Tharapos, M. and Sidaway, S. (2014). Downward accountability for a natural disaster recovery effort: Evidence and issues from Australia's Black Saturday. Critical Perspectives on Accounting, 25(7), 633-651. 
Te Rūnanga o Ngāi Tahu. (2016). Annual General Report, Retrieved from: http://ngaitahu.iwi.nz/investment/ngai-tahu-annual-reports/2016-annual-report/

Te Rūnanga o Ngāi Tahu. (2017). Annual General Report, Retrieved from: http://ngaitahu.iwi.nz/investment/ngai-tahu-annual-reports/2017-annual-report/

Te Tapuae o Rēhua Trust. (2014). He toki ki te Mahi Trades Training Trust, Retrieved from: http://www.tetapuae.co.nz/projects/he-toki-ki-te-mahi/

Treasury New Zealand (2016). Regulatory Impact Statement: ris-mcdemmfe-ker-dec16, Retrieved from: http://www.treasury.govt.nz/publications/informationreleases/ris/pdfs/ris-mcdemmfeker-dec16.pdf

UNISDR (2005). Hyogo Framework for Action 2005-2015: Building the Resilience of Nations and Communities to Disasters, Geneva, Switzerland: The United Nations Office for Disaster Risk Reduction.

UNISDR (2015). Sendai Framework for Disaster Risk Reduction 2015-2030, Geneva Switzerland: The United Nations Office for Disaster Risk Reduction.

United Nations (2008). Disaster Preparedness for Effective Response Guidance and Indicator Package for Implementing Priority Five of the Hyogo Framework, United Nations New York and Geneva, Retrieved from: http://www.unisdr.org/files/2909 Disasterpreparednessforeffectiveresponse.pdf

Walker, S. P. (2014). "Drought, resettlement and accounting", Critical Perspectives on Accounting, Vol. 25, No. 7, pp. 604-619.

World Bank (2013) Mapping Context for Social Accountability, Social Development Department, Washington, DC: World Bank.

World Bank Institute (2005). Social Accountability in the Public Sector, Washington DC: WBI Working Paper No.33641.

World Bank (2014). Social Accountability: What does it mean for the World Bank?, Social Accountability Sourcebook, Chapter 2, Washington, DC: World Bank.

Wright, M. (2012). Christchurch quake response faulted, Christchurch-quake-response-faulted. Stuff, Retrieved from: http://www.stuff.co.nz/national/7777292/Christchurch-quakeresponse-faulted, 2ed October. 
